\title{
E-learning as a Strategy of Acquiring a Company's Intellectual Capital
}

\author{
Jerzy Kisielnicki and Olga Sobolewska \\ Faculty of Management, Warsaw University, Warsaw, Poland
}

\author{
jerzy@kisielnicki.edu.pl; ola@sobolewska.net
}

\begin{abstract}
In today's world more attention is paid to training employees. A trained employee is the source of competitive advantage over other companies functioning in the sector. By training the employee we create and, at the same time, trigger the increase of intellectual capital in the organization. This article aims at analyzing the relations that occur between the training, taking into particular consideration the e-learning training and the increase of intellectual capital of the companies trained.

Training, as one of the fundamental methods of creating the intellectual capital of the company, can be carried out by means of several strategies. Training employees by specialized companies, which in order to do that use different kinds of forms, including e-learning, is one of them. Relatively few companies, however, decide to train their employees using e-learning technology. In practice, the most common strategy is training the employees using a blended-learning strategy, which means a strategy that is supplemented with meetings led by a coach. Both, the organizations training the employees using e-learning, as well as blended-learning technology are the subject of the analysis presented in this article.
\end{abstract}

Keywords: e-Learning, intellectual capital, trainings, e-Learning trainings, company training, knowledge (intangible) assets, New Economy, company's development.

\section{Introduction}

Currently, there are over 300 training companies in Poland that are registered in the Polish Chamber of Training Companies. Several small and non-associated organizations that also deal with training for companies and private clients should be added to that number. About $30 \%$ of training companies use e-learning methods.

In the analyzed enterprises there are two contradictory tendencies.

- The first tendency is the necessity of constantly training the employees in order to adjust their qualifications to the requirements of a contemporary organization functioning in a

Material published as part of this publication, either on-line or in print, is copyrighted by the Informing Science Institute. Permission to make digital or paper copy of part or all of these works for personal or classroom use is granted without fee provided that the copies are not made or distributed for profit or commercial advantage AND that copies 1) bear this notice in full and 2) give the full citation on the first page. It is permissible to abstract these works so long as credit is given. To copy in all other cases or to republish or to post on a server or to redistribute to lists requires specific permission and payment of a fee. Contact Publisher@InformingScience.org to request redistribution permission. turbulent and constantly changing world. The management of the company realizes that without training its competitiveness decreases and, at the same time, the value of the company lowers.

- The second is a tendency to look for savings by reducing the costs not connected directly 
with its activity, that is, reducing, among others, the costs of training, as well as maximization of direct work of employees in the company (training most often means taking the employee away from his current work)

The management of a company faces a dilemma of making such decisions that will enable finding a strategy that is acceptable from the point of view of the incurred expenses, as well as those that lead to the increase of the company's value. The problem is how, while making decisions in the scope of training, to take into consideration those two presented tendencies. The consequence of the decision is the choice of a successful and effective strategy of training that will combine the above mentioned trends.

We believe that it is the e-learning strategy that realizes the criteria of successfulness and effectiveness of training to the fullest, and we will try to justify that later in this article. The article is a fragment of broader research on e-learning and presents the role of training companies in acquiring the intellectual capital. The structure of the article is as follows:

Part one - the analysis of literature of the subject and, based on that, an attempt to present the role of training, particularly the e-learning training, in the acquisition of the intellectual capital.

Part two - survey research expanded by direct interviews that aim at justifying the hypothesis that the role of training companies conducting the e-learning training is rising and that companies chose it more often to increase their value on the market.

Since it is impossible to present the relationship between the intellectual capital and training activity in a quantitative way, as is shown further in the article, this impact is presented in an indirect way. We suppose that the direct result of the training is growth of an employee's skills and competencies. This fact influences the amount and the quality of intellectual goods, which is synonymous with the growth of the company's intellectual capital. We did not concern ourselves with the problem of training and its influence on an employee's career patch. The research was concerned with the employers' and employees' (as the participants of the trainings) feedback about the usefulness of the training. We analyzed training from the area of management, accounting, and finances.

Similar subject matter, that is the influence of training employees on the increase of the intellectual capital, is being dealt with, among others, by C. Argyris (1999), B. Levitt and J. March (1988), and an indisputable authority in knowledge management, K. Sveiby (2001). These researchers related with the presented problems themed, in particular with the methodological problems of models analysis and the various e-learning forms of development, as developed in many authors' works. Especially important issues are published by the Interdisciplinary Journal of ELearning and Learning Objects (IJELLO). Especially interesting are works that deal with the problem of e-learning - its models and development areas that are presented by E. B. Cohen and M. Nycz (2006), M. W. L. Fong and R. Sims (2010), M. Tate and D. Hoshe (2009), and A. Koohang, L. Riley, T. J. Smith, and J. Schreurs (2009)

\section{The Concept of Intellectual Capital - Methods of its Measurement and the Role of Training}

While analyzing the literature of the subject matter, especially the works of K.E. Sveiby (2001), three stages in the development of the intellectual capital concept can be observed. The first stage was in the 1980's, when the term intellectual capital was limited only to human resources management. The second stage in the development of research on issues concerning the intellectual capital occurred 1991-1997. It was the time of tele-information network development, including the Internet, which became a global network in the full sense of the word; a network universally 
available all around the world (almost!). At present we are at the third stage of intellectual capital science development. Such postulates can be found in numerous studies, not only of the above mentioned K.E. Sveiby (2001), but also G. Probst (Probst, Raub \& Romhardt, 2002), P. Lambe (2007) or B. Levitt and J. March (1988). Today, managing corporate knowledge is not only a duty of a particular department of a company (Human Resources or IT), but it is incorporated as an integral element of management of the whole enterprise strategy. An economy based on knowledge management is possible only if the organization has the intellectual capital at its disposal and is able to acquire, create and, use it in an effective way at the same time.

\section{Tangible vs. Intangible Assets of the Company}

Managing the company is a process comprised of several factors. Authors such as K.E. Sveiby (2001), C. Lee and J. Yang (2000) or B. Levitt and J. March (1988) more often see the organization as a value network, which is understood as "interaction between people playing different roles and connected by different relations, creating both non-material values (knowledge, ideas) as well as material value (money)" (Sveiby, 1997). Inside the organization, knowledge gained in different ways influences the system of assets of the company, which then influence one another (Figure 1a). None of the influences can be examined separately since the picture of organization is then distorted. Knowledge management encompasses all spheres of assets (not only the intangible ones). By introducing training to the company's policy as an element of the knowledge management process, a cycle is created in which there are constant resources influencing one another (Figure 1b). In that way a closed circle of relations is formed in which the following processes that occur one after another can be singled out:

1. Tangible assets (including financial assets) of the company are engaged in the process of employee training.

2. By employee training, intangible assets of the enterprise are increased.

3. Intangible assets, that is, the so called intellectual capital of the company, are used in order to enlarge the tangible assets of the company.

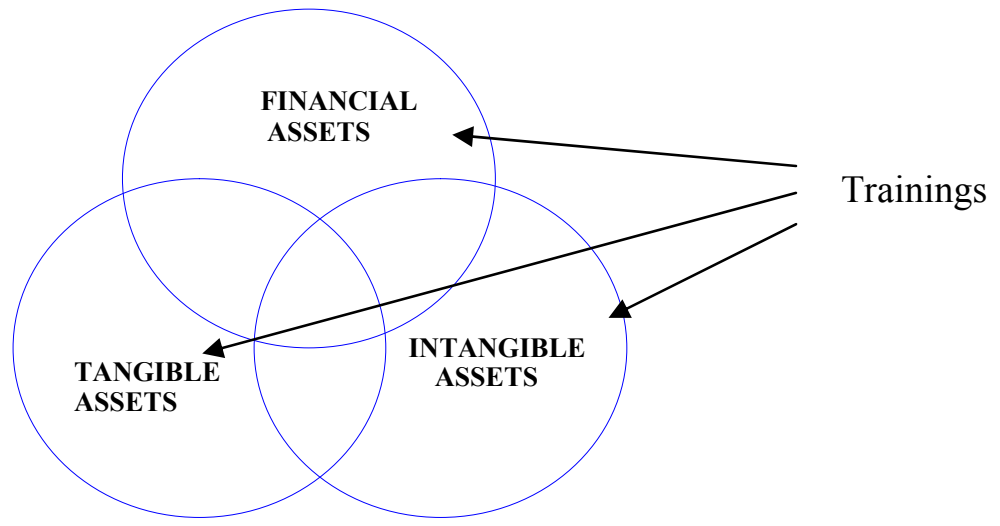

Figure 1a. The system of financial, tangible and intangible assets in the company and the influence of training (Source: Smith, 1998)

\section{The Role of Training in Knowledge Transfers}

As important is the influence of factors that are outside the internal structure of organization. Contemporary organizations are forced to constantly communicate with the environment because many times it is the stimuli coming from outside the organization that decide on its market success or failure. Therefore, the opinion that one of the most important, if not the key, aspect is at- 


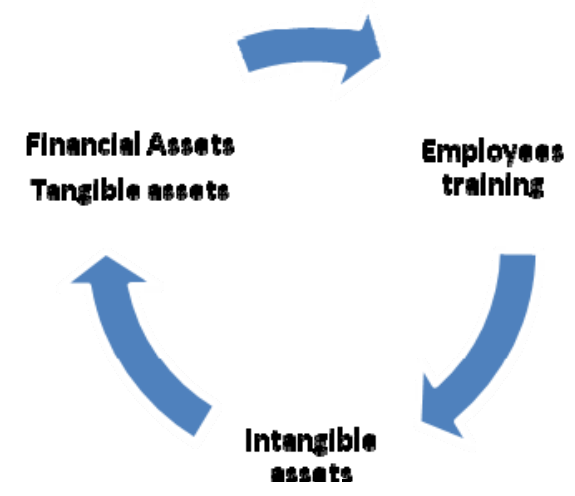

Figure 1b. The system of financial, tangible and intangible assets in the company and in the influence of trainings - knowledge management cycle (Source: own work)

tention to building an effective transfer system, and conversion of knowledge to and from the organization is becoming more and more popular. This transfer has to be bidirectorial since in today's conditions we have to deal with blurring the borders and the necessity of cooperation with a wider environment more often (Figure 2).

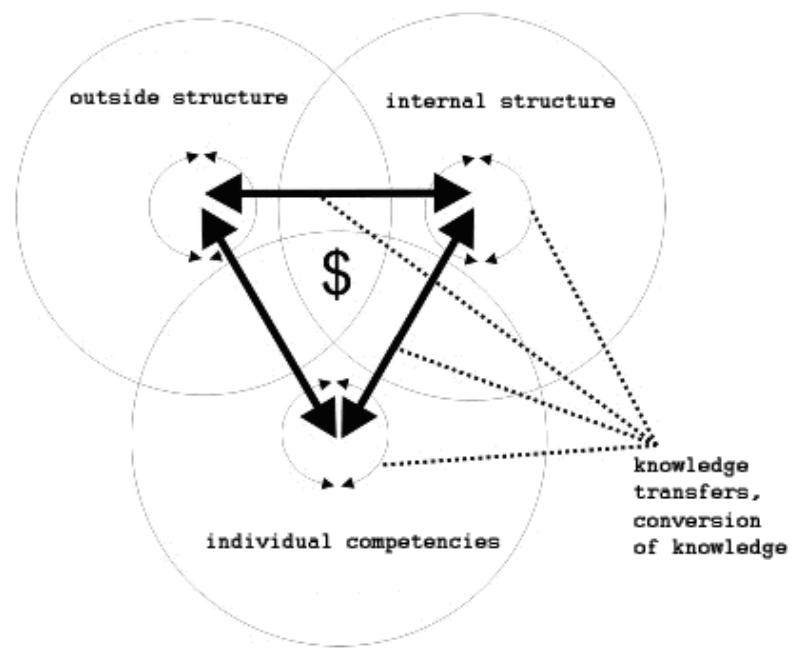

Figure 2. Image of a company from the perspective of knowledge

(Source: Sveiby, 2005)

Although the financial assets are usually presented as separate in comparison with the tangible assets, literature on the subject often divides the resources of the company into two groups: tangible and intangible capital. Table 1 presents the differences between these two. 
Table 1. The difference between the tangible and intangible assets (Source: Hunter, 2002

\begin{tabular}{|c|c|c|}
\hline & Knowledge assets (intangible) & Physical assets (tangible) \\
\hline $\begin{array}{l}\text { The possibility of } \\
\text { simultaneous } \\
\text { availability }\end{array}$ & $\begin{array}{l}\text { Being used by one entity does not } \\
\text { limit simultaneous use by another }\end{array}$ & $\begin{array}{l}\text { Being used by one entity excludes } \\
\text { simultaneous use by another }\end{array}$ \\
\hline Depreciation & $\begin{array}{l}\text { Does not depreciate, but if it does, } \\
\text { then it is usually quick }\end{array}$ & $\begin{array}{l}\text { It depreciates and can be either fast or } \\
\text { slow }\end{array}$ \\
\hline Transfer costs & $\begin{array}{l}\text { Difficult to estimate (it increases } \\
\text { together with the level of hidden } \\
\text { knowledge) "tacit portion" }\end{array}$ & Easy to estimate \\
\hline Property law & $\begin{array}{l}\text { Limited (patents, business secrets, } \\
\text { copyrights, trademarks) and difficult } \\
\text { to define, even in the well-developed } \\
\text { countries }\end{array}$ & $\begin{array}{l}\text { Usually full and clear - at least in the } \\
\text { highly well-developed countries }\end{array}$ \\
\hline $\begin{array}{l}\text { The possibility the } \\
\text { property law } \\
\text { enforcement }\end{array}$ & Rather difficult & Definitely easy \\
\hline
\end{tabular}

\section{Intellectual Capital in Literature and Business Practice}

The concept of intellectual capital is depicted in various ways in the literature of the subject matter. If interested, except the already mentioned authors, we recommend, among others, works by P.M. Senge (2006) and L. Edvinsson and M. Malone (2001).

In citing S. Arvidsson (2003), it can be noticed that the taxonomies presented are usually based on two criteria: management and financial. In the case of the first criterion, the authors concentrate on such company management that appreciates the role of intellectual capital in creating competitive advantage. In this case we deal with strategic management and the position of intangible capital in the company's strategy. In the second case, the literature mainly deals with the methods of classification of intangible assets in different types of reports. The intellectual capital is defined in many ways. G. Petrash from Dow-Chemical treats the concept of intellectual capital as knowledge (Perechuda, 2005), but such knowledge, which can be transformed into value, is specific profits for the company. A. Ward is the author of an interesting view on this issue. He claims that the intellectual capital is a sum of "islands of knowledge" that function in the company (Perechuda, 2005). For the needs of accounting standards it was necessary to introduce a less poetic but much more measurable definition, and, although it is limited since it encompasses only a part of the intangible assets of a company, it is possibly the best definition we have at our disposal. According to this definition the intellectual capital of a company is the difference between the market value of the company and its book value. This difference, according to the authors of the definition, results from the use of modern technologies by the company, the use of particular skills that the company or its employees have and what we call the company's intellectual capital management (a similar view is presented by A. Jaspahara, 2006). Table 2 depicts the influence that the intellectual capital has on the market value in selected companies. 
Table 2. The difference between the book value and the market value ( October 2009) (Source: own work based on above-mentioned companies data reports)

\begin{tabular}{|c|c|c|c|}
\hline Organization & $\begin{array}{l}\text { Market value in mon- } \\
\text { etary units }\end{array}$ & $\begin{array}{l}\text { Market value in ac- } \\
\text { counting units }\end{array}$ & $\begin{array}{c}\text { PBV } \\
\text { (Price/Book Value) }\end{array}$ \\
\hline \multicolumn{4}{|c|}{ International organizations } \\
\hline Coca Cola & 23654 & 125968 & 5,3 \\
\hline Ford & 32313 & 22715 & 1,0 \\
\hline Deutsche Bank & 34843 & 37895 & 1,1 \\
\hline Roche & 55 & 146 & 2,6 \\
\hline IBM & 1383 & 160 & 8,7 \\
\hline Microsoft Corporation & 1052 & 237 & 4,4 \\
\hline Oracle & 26487 & 107285 & 4,1 \\
\hline Yahoo! & 11920 & 24545 & 2,1 \\
\hline B. $\quad$ Polish organiz & & & \\
\hline KGHM & 10557 & 17280 & 1,6 \\
\hline PKO BP & 19910 & 39157 & 2,0 \\
\hline Sygnity & 298 & 177 & 0,6 \\
\hline Multimedia Polska & 637 & 1317 & 2,1 \\
\hline Ciech & 874 & 1117 & 1,3 \\
\hline BRE & 4133 & 5891 & 1,4 \\
\hline Comarch & 505 & 557 & 1,1 \\
\hline Agora & 1195 & 1166 & 1,0 \\
\hline
\end{tabular}

\section{Learning Organizations in New Economy}

The difference described above results from the particular skills of the company that not only possesses intangible assets (which in itself are not an innovation), but also knows how to use them. Practically every organization has a range of goods that can be qualified as intangible resources. These are patents, business secrets, extensive experience, or the skills and abilities of the personnel. It turns out, however, that just having these resources is not a condition that is enough to be successful on the market. On the market there are organizations that start from level zero, but thanks to being provided a constant gathering of resources (including intangible ones) and learning, they become ranked among the biggest market players relatively fast. Examining the meaning of the intellectual capital and at the same time separating it from the subject of training and lifelong learning would be pointless. Modern organizations that take up the challenges of the New Economy must be the learning organizations. A. Sokołowska emphasizes that, while analyzing the learning organizations, we can distinguish two trends (Perechuda, 2005). First of all, such organizations are understood in dynamic organizational categories that are oriented at their development, searches for new chances on the market and continually increases their effectiveness, efficiency and flexibility. The second group of learning organizations consists of such entities that choose growth through development of their employees. Organizations of this type create conditions and encourage their members to constantly improve their qualifications and skills. It is easy to notice that both these trends supplement each other and contemporary organizations should 
strive to combine the features of both. However, a point of departure is always becoming aware of the need to develop; that is the need of lifelong learning (Figure 3).

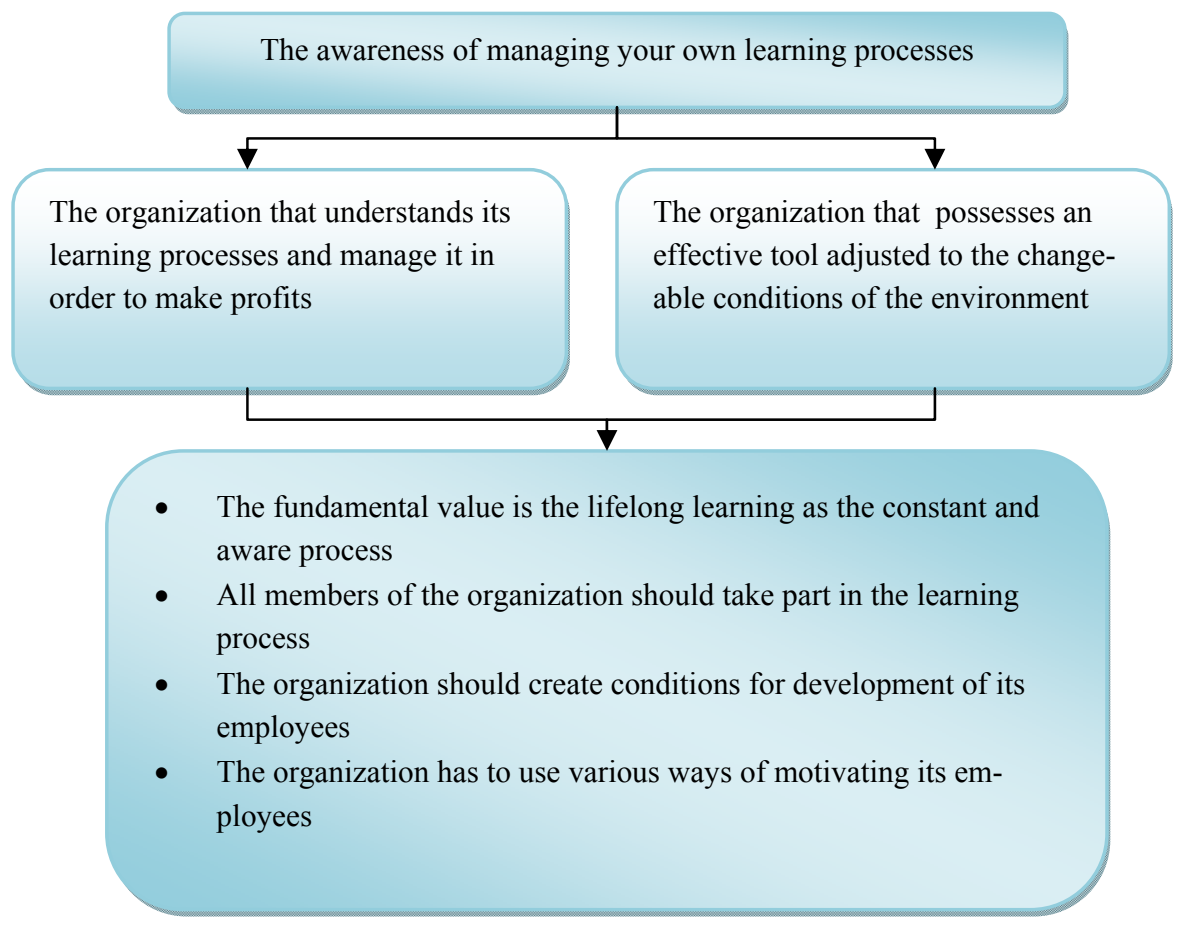

Figure 3. The main assumptions of functioning of a learning organization

(Source: A. Sokołowska in Perechuda, 2005, p. 135)

\section{The Culture of Training}

Introducing the culture of training is the condition of gaining numerous profits by the company, such as, among others, the increase in the value of products and services, and as a result, greater client satisfaction and market share. The continued ability to adapt to the turbulent conditions of the environment is impossible for organizations that do not learn. The ability to make changes requires engagement in the process of learning since it is impossible to develop oneself without broadening knowledge. In a word, in today's conditions the ability of learning is one of the features that must be developed in the process of enterprises' evolution. The companies that do not tend to gain new knowledge are bound to act according to the known, common schemes, which will turn out to be outdated and ineffective. Such organizations will be forced to withdraw from the market and, at best, their activity will be significantly limited.

Other authors, aside from those already mentioned, who deal with the subject of building the conditions for effective learning for the organization are D. Garvin (2006), R. Stata (1989) and G. Huber (1991). The beginning of this relationship chain stressed by several authors, including $\mathrm{G}$. Probst (Probst et al., 2002), is the introduction to the enterprise of the custom of conducting training for employees and creating an atmosphere that supports broadening knowledge and motivating said employees to making such efforts. The authors listed by us dealt mainly with traditional training.

G. Probst emphasizes that employee training directly influence:

1. Better use of the available technologies (which, thanks to the training, cease to be strange and unfamiliar to the employee) and the ability of easier use of conclusions from the pre- 
vious projects and experiences (also one of the remarks in C. S. Nam and T. L. Smith Jackson's (2007) reflections

2. Reduction of the mistakes made at the operational level, which is directly connected to the reduction of costs

3. The ability of making fast decisions by the employees, more efficient orders delivery, and shortening the time between the project phase and setting about realization of the project

4. Strengthening the employees' motivation to use the knowledge, situation in which the employees have the access to, and, significantly, are willing to use the additional, often useful knowledge

These factors are the source of effects that consist of a better recognition of client needs. They also influence better adjustment of the product or service to the final needs of recipients and improvement of the client service and the client's order delivery. That way the author proves the direct relationship between employee training and the company's profitability.

\section{Intellectual Capital and the Company's Development in the New Economy Environment}

As it is underlined by the scientists who deal with research on the animal world, the intelligence of the herd is the factor guaranteeing that species will survive. The researchers claim that "Ants are not intelligent. It is the colony of ants that is intelligent (...) The colony is capable of solving problems which absolutely exceed the reach of an individual" (Levitt \& March, 1988). Critical animals' problems, such as finding a place for a new anthill or beehive, watching out for and escaping the predator, are successfully accomplished by the colony. The colony's intelligence consists of interactions between separate individuals and quick reactions to stimulus from the closest, often anonymous environment. As the author of the article concludes, "crowds become wise only when their individual members are responsible for what they do and make their own decisions. The group will not be intelligent if its members will imitate or servilely submit to trends or wait till somebody tells them what to do"(Miller, 2007). People are members of the animal world, and although, unlike an ant or a bee, we are intelligent beings, the truth about the power of a herd relates to us as well. Attaining the synergy effect, that is the surplus value, which is the result of resources' accumulation and their use, is undoubtedly the goal of every organization. It also constitutes a necessary condition for the organization that wants to function effectively in the environment dictated by the New Economy.

A contemporary enterprise is forced to search for, improve, and implement new and different business models that have an impact on:

- product / service offered by the company, which is particularly noticeable as a tendency to shorten the life cycle of the products

- clients and business partners who expect to be delivered totally new surplus value by the company

- the organization itself, by changing the phases and the life cycle of the organization, or the necessity to unconventional search for new key competencies, which aer mainly based on the intellectual capital of the enterprise

J. Kisielnicki (2005), K. Perechuda (2005) and M. Stankiewicz (2006) write about the transformation of enterprises from the traditional models into modern management models; the problem that Polish companies have already faced or will have to face in the nearest future in more detail. 
Thanks to the proper use of knowledge resources, the New Economy causes the company to win and maintain its position on the market. Knowledge management is defined as "all the processes which manage creation, spreading and influence on knowledge in such a way, so as it is possible to accomplish the company's goals" (Lee \& Yang, 2000). According to Lee and Yang, the intellectual capital management does not concentrate on "doing things right" anymore, but on "doing the right thing" (Lee \& Yang, 2000). At the same time it should be kept in mind that any knowledge that the company manages must continuously be powered and updated. The organizational culture has to contain numerous motivators to constantly broaden that knowledge. This phenomenon has already been noticed by individual human beings; what is particularly manifested by the huge interest of universities and other types of schools in postgraduate education. Similarly to people, economic organizations will not only have to notice the requirements of the present, but also adjust to them. This adjustment has to go in two stages. First, it is essential to become aware of the necessity of corporate knowledge development and take actions that aim at the development of intangible assets of the company, and then taking particular actions from the scope of implementing knowledge management systems and elimination of numerous barriers that occur and that significantly decrease the effectiveness of the adopted strategies, in particular knowledge acquisition strategy (Figure 4).

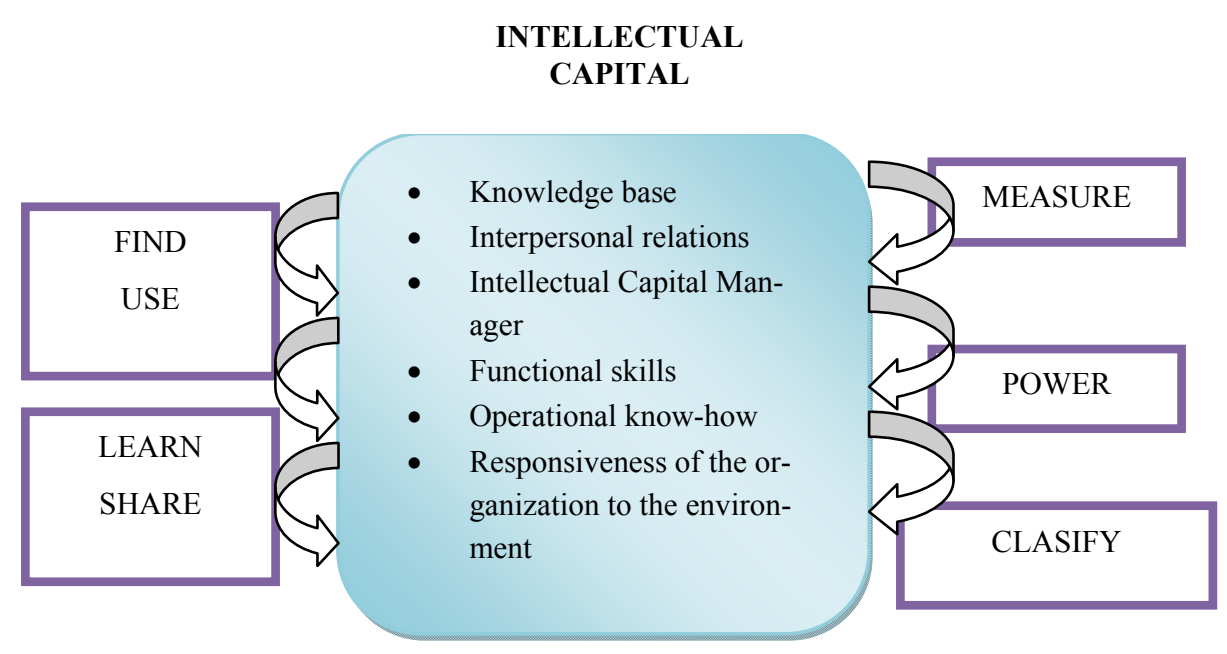

Figure 4. The process of intellectual capital management (Source: Drawn up on the basis of Bukowitz \& Williams, 2001)

\section{The Influence of Training on the Intellectual Capital of the Organization}

A. Choo, K. Linderman and R. Schroeder (2007) confirm our previous statements on knowledge as a strategic resource used by the company in order to develop its competitive advantage. For enterprises, knowledge development is connected with the previously mentioned stages of becoming aware of the necessity of knowledge management and development and implementation of strategy, as well as elimination of numerous barriers that occur. In the case of implementing knowledge management strategy, companies possess two strategies known as: codification strategy and personalization strategy (Edvinsson \& Malone, 2001). The codification strategy takes place when the information system constitutes the source of knowledge in the company. Knowledge is in the information infrastructure and is acquired from this place. Computer systems and software are in this instance the main knowledge stock. The personalization strategy in turn assumes that the source of knowledge is a human. People are closely related to knowledge; they acquire it and develop it. Organizing different types of training methods aim at increasing the 
employee's knowledge resources, and what is inseparably connected with that - the company's intellectual capital - is the way this strategy is realized.

According to the authors of this article, the above mentioned strategies can and even should supplement each other. The reality in which today's companies function forces such a mixed approach. The most effective strategy is the mixed strategy in which both the information system and a human are the source of knowledge. The mixed strategy assumes that both these sources of knowledge cooperate with each other, which in turn, requires having the ability of working with the information systems and using the management information infrastructure. Regardless of the choice of strategy the company decides to train employees since, even though we assume that it chooses the codification strategy - the employees will be forced to use a rich and well-developed information system and developed bases and data warehouses. While deciding to train employees enterprises can choose an option in which this task is realized by themselves, e.g., by the HRM departments, or can use the services of specialist training companies (outsourcing approach). There is also an option in which the enterprise shifts the duty of training on the employees, which, however, is not, according to the authors, an effective solution for the company.

The following intellectual capital acquisition path, in which the training subject is an independent external company, is analyzed in the article (Figure 5). Teaching does not have to be conducted only in the traditional way (classroom-lesson system). Enterprises possess e-learning technology and the mixed method, that is such a method where part of the lessons are realized in the traditional way (there is a face-to-face meeting of a teacher and students), and the other part is carried out with the use of computers and teleinformation networks (Figure 6).

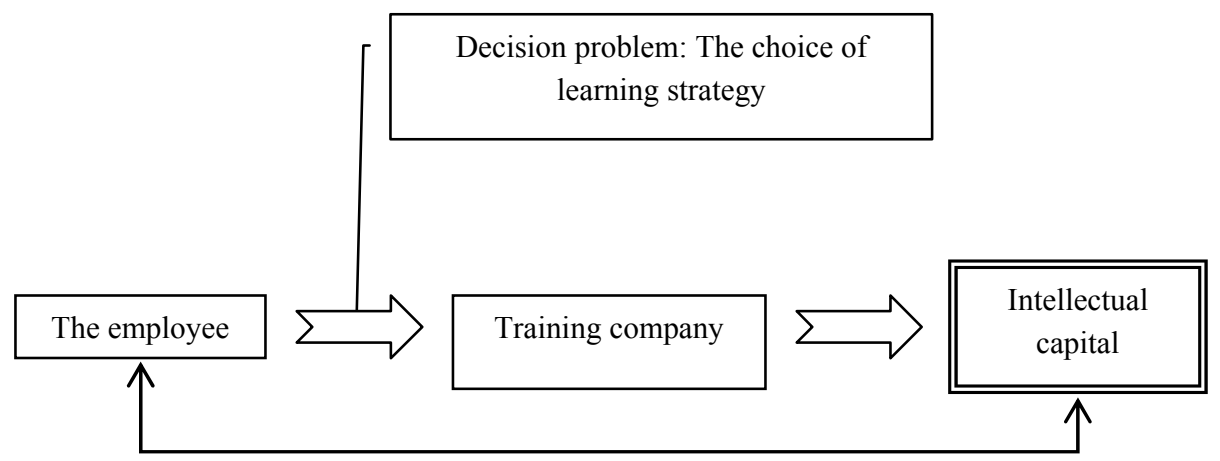

Figure 5. Intellectual capital acquisition path in the company (Source: own work)

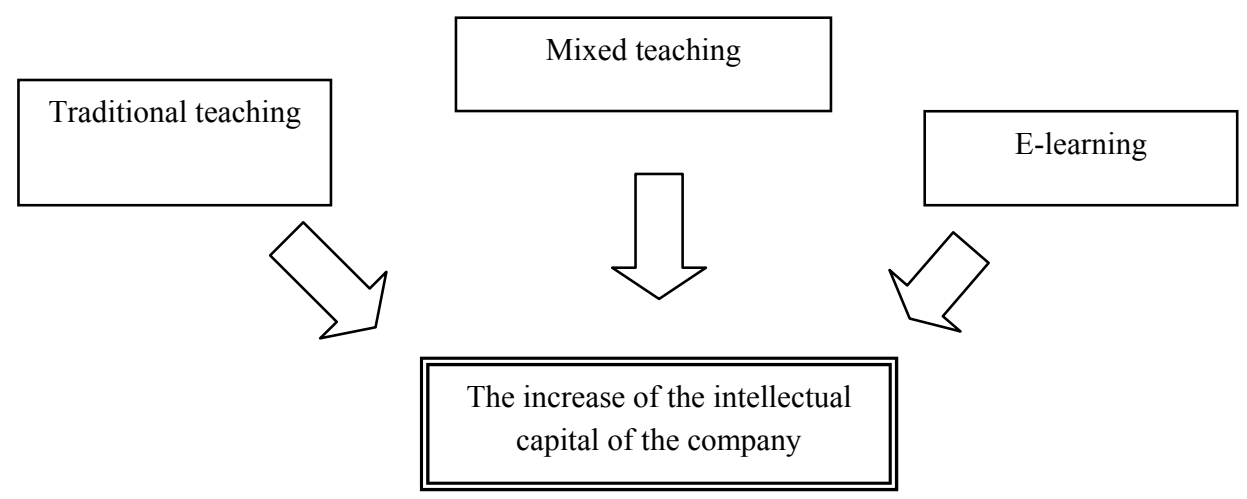

Figure 6. Teaching strategies and their influence on the increase of the intellectual capital (Source: own work) 
Depending on which strategy is chosen by the company, we deal with the options presented in Table 3. Each of the options mentioned is connected with specific costs that the client company incurs. For instance - the first option means not only the cost of hiring the training center, but also the cost of an employee's journey to the training, the accommodation expenses and the costs connected with the employee's absence at work on that day. On the other hand, the strategy of conducting trainings with the use of e-learning technology requires investment connected with the purchase or the cost of access to the hardware platform and the specialist computer equipment, for example the interactive board. However, it should be emphasized that for most companies functioning on the market, the computer system is the standard element of equipment, so this barrier is not significant.

Table 3. The matrix of the available training strategies

\begin{tabular}{|c|c|c|c|c|}
\hline $\begin{array}{l}\text { Item num- } \\
\text { ber }\end{array}$ & Description & $\begin{array}{l}\text { Traditional } \\
\text { training }\end{array}$ & $\begin{array}{l}\text { E-learning } \\
\text { training }\end{array}$ & Mixed training \\
\hline 1 & The training takes place in an external training center & $\checkmark$ & & $\checkmark$ \\
\hline 2 & The training takes place in the client's headquarters & $\checkmark$ & $\checkmark$ & $\checkmark$ \\
\hline 3 & $\begin{array}{l}\text { The training takes place in the training company's } \\
\text { headquarters }\end{array}$ & $\checkmark$ & & $\checkmark$ \\
\hline 4 & $\begin{array}{l}\text { The training is carried out on the e-learning platform } \\
\text { which belongs to the client company }\end{array}$ & & $\checkmark$ & $\checkmark$ \\
\hline 5 & $\begin{array}{l}\text { The training is carried out on the e-learning platform } \\
\text { which belongs to the training company }\end{array}$ & & $\checkmark$ & $\checkmark$ \\
\hline 6 & $\begin{array}{l}\text { The training is carried out on the open-source platform } \\
\text { (e.g. moodle) }\end{array}$ & & $\checkmark$ & $\checkmark$ \\
\hline
\end{tabular}

The costs connected with the necessity of training the employees in the use of the e-learning platform should also be taken into consideration, however, as the research carried out by the authors show (Sobolewska, 2006), the cost of employees' training is small and is falling to zero successively. It results from the fact that computers and their operation are becoming everyday tools in a professional life, and e-learning platforms are designed in such a way as to resemble what the users already know with programmes in terms of appearance and functioning. In a word, although we cannot forget about this position while analyzing the costs of e-learning, we should not overestimate it.

While analyzing the costs of training prepared by the training company it can be stated that the choice of the training strategy, that is the choice between traditional teaching and e-learning results in the occurrence of different expenditure items. In the case of training with the use of a traditional method the price that must be paid for the course will definitely include:

1. Preparation of the training content

2. The work of a coach / teacher

3. Preparation of the additional materials for the participants of the course

4. The cost of the place where the training takes place - assuming that it takes place outside the client company's headquarters, but even in such a situation it is necessary to have or prepare an appropriate base to carry out the training, which also requires some financial outlays

For the e-learning training the costs will look slightly different. They will certainly include:

1. Preparation of the training content

2. The purchase of the e-learning platform, assuming that the company will decide to buy such software, since there is a possibility of using open source systems free of charge 
3. The possibility of using the e-learning platform which is the property of the training company - if the client decides on such a solution

4. Training the employees so that they could competently use the e-learning platform

5. Computer equipment which will enable using the remote teaching technology, however it should be emphasized that in most cases the employees who participate in the training can use the computers which are in their workplace

6. The place of training - sometimes there is no need to specially prepare the place of training since the employee can learn in the place where he/she works.

While analyzing the costs it can be noticed that the initial costs connected with learning using the e-learning strategy are higher than in the case of the traditional training. However, it is worth carrying out the analysis not only from the perspective of total costs, but also the unit costs, that is, the cost of training one employee. The cost of training is divided into a particular number of people by the client company, while in the training conducted in a traditional way the number of employees trained can be significantly lower than in the case of e-learning. The comparative analyses, according to the training, costs were conducted in 2007-2010. There were about 30 training companies and 5 academies using both e-learning technologies and traditional training methods, engaged in the survey. The survey was executed by the questionnaire and experts' panel discussion, which consisted of the trainers and the training administrators. The research aimed at definition of the costs changes in e-learning and traditional training styles. Analyzed organizations conducted training from the area of management, accounting and finances. We had to approve the limitations such as how to compare the training organization's size and even the form of the conducted training, so it was impossible to deduct very detailed conclusions. We focused our attention on the change of training costs over a course of time. The necessity of conducting the same training for another group of employees in a traditional way makes the company incur almost the same expenses again, while in the case of e-learning those expenses decrease considerably. In the opinion of our experts, preparation and leading one hour of the e-learning training demands about 10-15 hours of the trainer's work in the initial phases. Afterwards, this time is shortened to about 4 hours. In relation to e-learning, traditional training is not fundamentally related to time. In the initial phases we need to engage more costs in preparing materials and syllabus but later the costs flatten (preparing 1 hour of lecture is estimated on about 4 hours but essential updates needs only 0,5 hour). Also, as time flows, the traditional training methods become more and more expensive, while the expenditure on e-learning essentially decreases as it is used. A company using such training can not only use the same courses several times (it can of course update them if needed), but also the costs of new training resources comprise only the cost of content preparation since the investment in infrastructure is practically a one-time expenditure.

Synthetic results of research carried out by J. Kisielnicki (2008) are presented in Figure 7. 


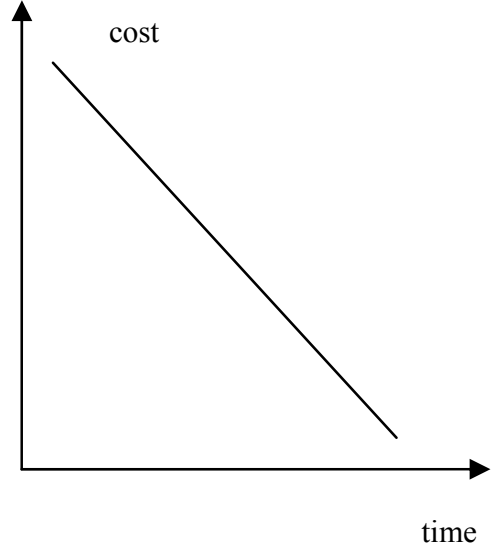

E-learning

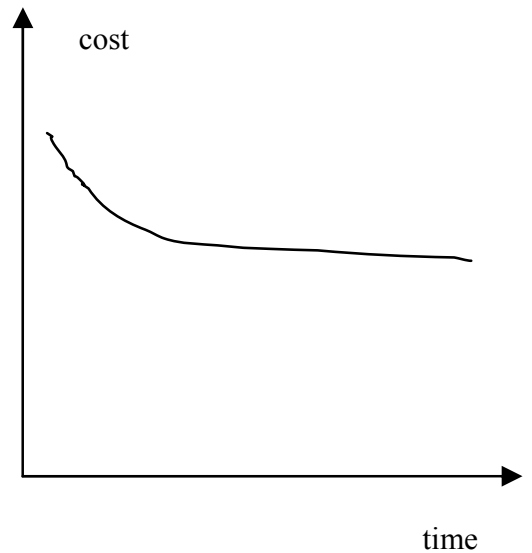

Traditional training

Figure 7. Comparison of traditional and e-learning trainings costs (Source: own work)

Cisco company (Vademecum, 2004), which has conducted the calculation of Return on Investment, has achieved analogical results. The calculation shows that the cost of training carried out online and the traditional training level off after about 5 months. In the next periods the cost of traditional training exceeds the costs of e-learning considerably. While analyzing the charts in picture 7 it can be explicitly stated that the company's investment in e-learning is long term. The calculation carried out by Cisco is presented below in Table 4 and Figure 8.

Table 4. ROI calculation for an example company (according to Cisco)

(Source: Vademecum, 2004)

\begin{tabular}{|c|c|c|c|c|}
\hline \multicolumn{5}{|c|}{ The characteristics of the company } \\
\hline \multicolumn{3}{|c|}{$\begin{array}{l}\text { - } \\
\text { - } \\
\text { - }\end{array}$} & $\begin{array}{c}500 \mathrm{mln} \\
100 \\
1000 \\
2 \mathrm{mln} \\
8 \\
50 \% \\
4 \\
30 \\
70\end{array}$ & \\
\hline & Year 0 (USD) & Year 1 (USD) & Year 2 (USD) & Year 3 (USD) \\
\hline \multicolumn{5}{|l|}{ Income } \\
\hline $\begin{array}{l}\text { Lower administrative } \\
\text { costs }\end{array}$ & & 624000 & 654000 & 654000 \\
\hline $\begin{array}{l}\text { Lower costs of delega- } \\
\text { tions }\end{array}$ & & 280000 & 280000 & 280000 \\
\hline $\begin{array}{l}\text { Higher productivity of } \\
\text { employees }\end{array}$ & & 1697000 & 1697000 & 1697000 \\
\hline Total income & & 2633000 & 2633000 & 2633000 \\
\hline \multicolumn{5}{|l|}{ Expenditures } \\
\hline $\begin{array}{l}\text { One-time investment } \\
\text { expenses }\end{array}$ & 900000 & & & \\
\hline Operational costs & & 142500 & 142500 & 142500 \\
\hline Total expenditure & 900000 & 142500 & 142500 & 142500 \\
\hline Cash flow & 900000 & 2490500 & 2490500 & 2490500 \\
\hline
\end{tabular}




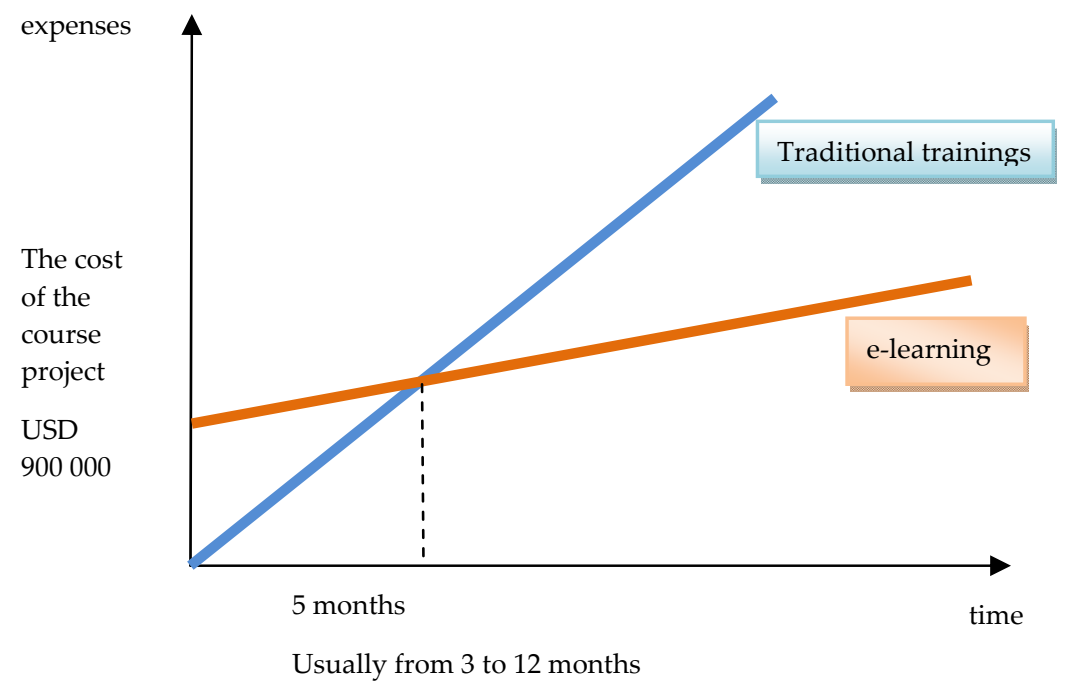

Figure 8. The comparison of traditional training and e-learning costs according to Cisco (Source: Vademecum, 2004)

\section{The Strategic Analysis of E-Learning Training}

In order to conduct the strategic analysis the SWOT method has been used. (SWOT is a tool that enables us to define the strong and weak points and the opportunities and threats of the object analyzed in the particular period of time (Kisielnicki, 2005)). The SWOT analysis is a tool that presents the strategic situation in a specific period of time. Because we function in a changeable world, very often what at that moment is considered an opportunity can become a threat later on or in different economic conditions. For instance, the possibility of adjusting the content of training to the individual requirements of the users can turn out to be a highly desirable feature, however very expensive, which in practice means that it is not used by the enterprise. On the other hand, a threat, which undoubtedly the limited access to the Internet network is, in the next few years can become only a historic barrier.

The SWOT analysis presented in this article is the outcome of a research survey and interviews. The research survey was carried out in two separate years 2007 and 2009. The first research was carried out among the training departments of 80 companies operating on the Polish market that were registered with the Polish Chamber of Training Companies and intended to take place in the survey. The aim of this research was to receive the answer to the question of whether "in the process of training the personnel companies use the e-learning technology" and whether elearning trainings that are available in their offerings occur as a frequently and eagerly chosen option (Sobolewska, 2006). The research of 2009 was conducted among 92 companies that deal with carrying out training methods dedicated to its employees. Employee training we analyzed, was conducted traditionally and via e-learning. Both in the first and in the second survey we asked about the attributes that are particularly important for employers (companies) and employees (that have been trained). Both of the surveys exhibited the strong and weak points of elearning trainings. The synthetic results of the SWOT analysis are presented in Table 5. 
Table 5. The SWOT analysis for the trainings conducted with the use of the e-learning method (Source: own work on the basis of the conducted research)

\begin{tabular}{|c|c|}
\hline Strong points $-S$ & Weak points $-W$ \\
\hline $\begin{array}{l}\text { - Adjusting the content of the training methods to the } \\
\text { individual needs of the participants (individualiza- } \\
\text { tion of pace and content) } \\
\text { - "I gain knowledge when I want to, that is my school } \\
\text { is wherever my laptop is" } \\
\text { - The possibility of training employees in the work- } \\
\text { place } \\
\text { - The possibility of quick reaction to changes in the } \\
\text { environment, that is new knowledge } \\
\text { - The easiness of absorption and transformation of } \\
\text { - } \text { pnowledge } \\
\text { - The possibilically unlimited number of students } \\
\text { - The interactivity of trainings } \\
\text { - The possibility of direct verification of the training } \\
\text { effects }\end{array}$ & $\begin{array}{l}\text { - The necessity of having technical resources to start the } \\
\text { training } \\
\text { - Laborious preparation of the first course } \\
\text { - Difficulties in extracting knowledge } \\
\text { - Dependence of the results of training on the reliability } \\
\text { of the computer equipment, software and the network } \\
\text { - High percentage of people who do not finish the train- } \\
\text { ing }\end{array}$ \\
\hline Opportunities - O & Threats - T \\
\hline $\begin{array}{l}\text { - The possibility gaining knowledge by those who, in } \\
\text { other conditions, would not have a chance to gain it } \\
\text { - The possibility of immediate exchange of opinions } \\
\text { - Quick reaction to the needs of the labor market } \\
\text { - Quick supplementation of the knowledge needed } \\
\text { - Higher effectiveness of sharing knowledge between } \\
\text { the participants of the process of learning than in the } \\
\text { traditional education systems }\end{array}$ & $\begin{array}{l}\text { - Equipment failure } \\
\text { - Lack of broad access to the Internet } \\
\text { - The economic barrier } \\
\text { - International competitors } \\
\text { - Lack of demand for such trainings } \\
\text { - Employers' resistance to treat this method of teaching } \\
\text { as a rightful method }\end{array}$ \\
\hline
\end{tabular}

The companies that responded to the survey unanimously stated that nowadays the employees' training is a necessity. They thought that in order to be successful a company needs well-trained personnel. As an answer to the question of which arguments convinced them to use the e-learning technology in training the employees they mentioned among others (Figure 9):

- Time flexibility of the training (the employee takes advantage of the training whenever it is most convenient to him). Thanks to that the training does not collide with important tasks of the employee that are impossible to postpone.

- Individualization, understood as the possibility of adjusting the content and pace of learning to the individual needs of the person trained and the possibility of coming back to some elements of the course if needed.

- The possibility of immediate verification of the effects of training. 
The necessity of engaging big resources during conducting the training

The necessity of additional, very often big investment

High cost of training content preparation

Big percentage of people not finishing the course

Other

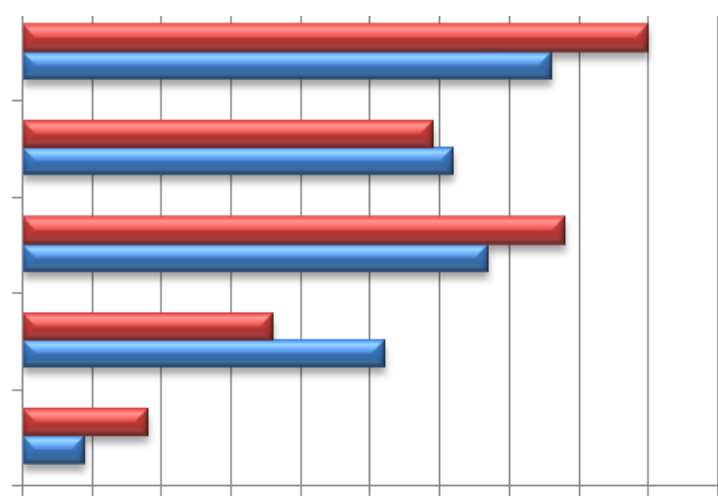

$0 \% \quad 5 \% \quad 10 \% 15 \% 20 \% 25 \% 30 \% 35 \% 40 \% 45 \% 50 \%$

\section{Figure 9. Factors which influenced the decision of conducting training for the employees with the use of e-learning technology}

(Source: own work on the basis of the conducted research)

The responders, when asked about the advantages of the e-learning training methods, pointed out the possibility for the employees of lifelong learning. They unanimously stated that e-learning is a much more flexible form than traditional training. In the case of e-learning, the training can be conducted at any time convenient for the employer and the employee (without colliding with already scheduled tasks or, e.g., with the planned holiday) and, especially important, the training can be carried out repeatedly for a large number of employees. The employers appreciated the fact that e-learning training style can be a form of using the corporate knowledge. Such training develops within the company (it is created by the employees) and based on the experience and behavior patterns of the company. That way the so called organizational culture can be developed, which would be much more difficult for the coach from the outside of the company (that is an external company).

E-learning training methods constitute an attractive form for the participants themselves. It certainly results from the flexible form of the training (the trainee not only decides on the time, but also on the intensity and the pace of the training), although the modernity of such form of teaching also seems to be attractive. About $20 \%$ of the respondents noticed that e-learning allowed reduction of teaching costs (problem of the costs was introduced in the prior part of the article). It surely concerns the companies that see the training in a long-term perspective (Figure 10).

As for disadvantages of e-learning training (Figure 11), the necessity of engaging big resources while carrying out the training was mainly mentioned. These are both the financial resources (as everybody knows the preparation of the e-learning training content is a rather expensive task), tangible resources (computers on which the employees work during the training must be properly prepared), and human resources (the training should be coordinated by the lecturer who helps in solving substantial problems, as well as by a person who will help if technical problems arise). Another significant disadvantage which results from the specificity of e-learning is the fact that a relatively large percentage of participants do not finish the course. It is a side effect of the flexibility of e-learning. Every participant of the course can independently plan his/her time for studying but requires a lot of self-discipline and meeting deadlines. The goal of the research was to point out the actual strong and weak points of the e-learning. Many factors that can influence on the participant's motivation were described in the fifth volume of IJELLO magazine (Hershkovitz \& Nachmias, 2009; Sela \& Sivan, 2009; Shamir-Inbal, Dayan \& Kali, 2009). Publications mentioned above are concerned mainly to school and academic learning, but there are many similarities with the subject of the employees' training. 


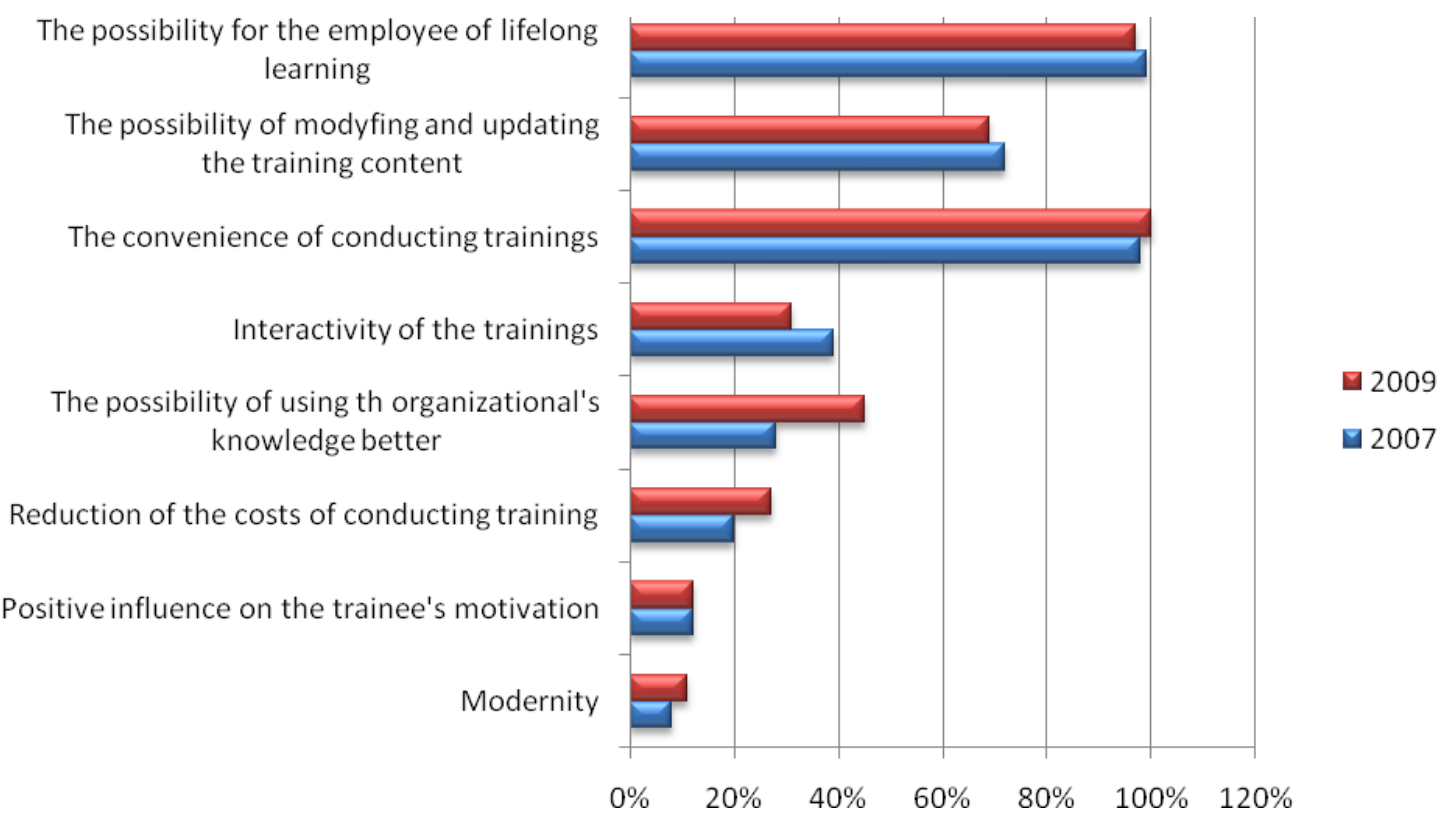

Figure 10. The advantages of e-learning trainings in the employers and trainings companies' opinion (strong points) (Source: own work based on the conducted research)

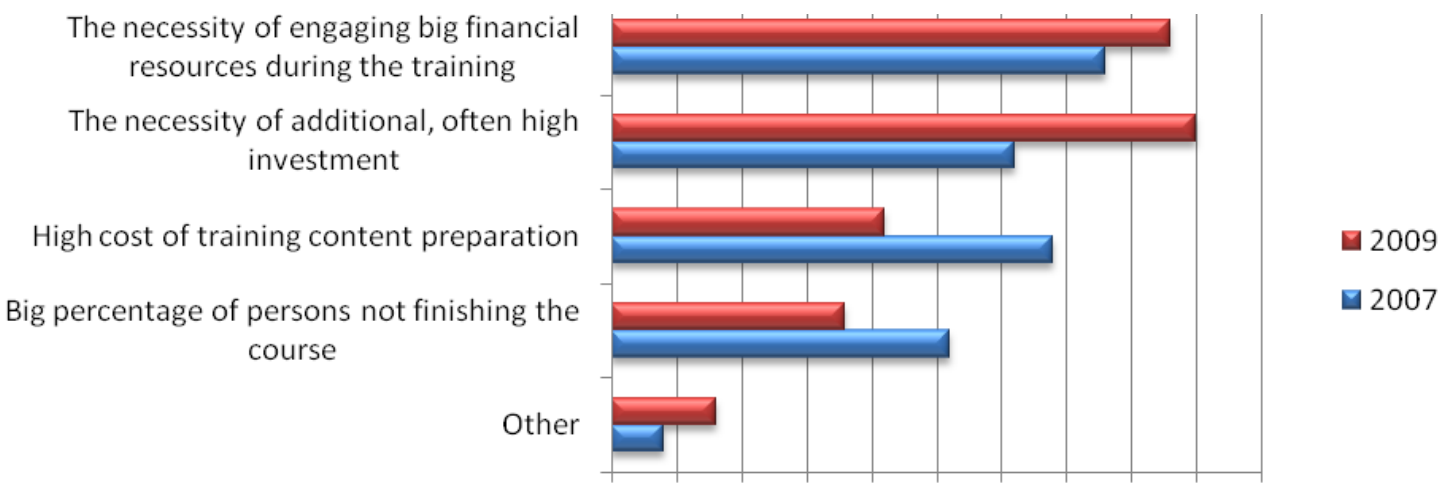

$0 \% \quad 5 \% \quad 10 \% 15 \% 20 \% 25 \% 30 \% 35 \% 40 \% 45 \% 50 \%$

Figure 11. The disadvantages of e-learning trainings in the employees and training companies' opinion (Source: own work based on the conducted research)

\section{Usefulness of the Training in Creating the Intellectual Capital of the Company}

Figure 12 presents another taxonomy of intangible resources which the company has at its disposal. The proposed division shows that resources divide into two categories: competence and relation resources. In the case of the first ones these are the skills that enable realization of a particular task. For instance, a good salesman should know negotiation techniques and an accountant should be perfectly familiar with the latest financial reporting provisions. Training for employees can allow supplementing the missing skills, as well as development and improvement. Intangible 
assets belonging to the relation category, on the other hand, are such resources that influence the performance of the company, even though they are not competences. These are, for example, good relationship with suppliers and good reputation of the company on the market or client loyalty, which is a very important factor in today's world. Similarly to the case of strengthening and increasing the competence resources, the training can be useful to create intangible assets. The training resources dedicated to business partners (e.g., wholesalers, middlemen) will enable better knowledge of the products offered by the enterprise and thanks to that, according to the rule that we accept things that are known to us more willingly, most probably people will have more trust in the company. The situation is similar when clients are considered. They will choose more enthusiastically the products or services of the companies that offer them full information about their offer and reliable service.

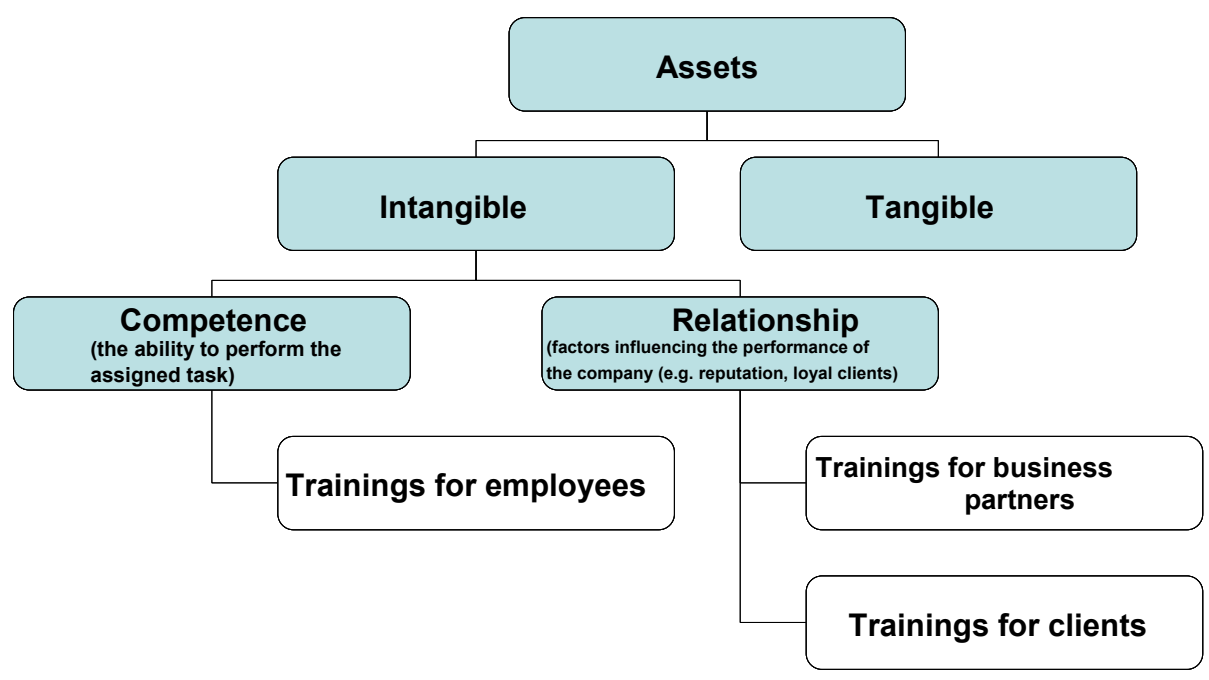

Figure 12. Trainings and the creation of the intellectual capital

(Source: drawn up on the basis of Di Tommaso, Paci, \& Schweitzer, 2002)

The survey research included a question concerning the course participants' (that is, the employees of particular companies) assessment of the e-learning training conducted. What is interesting; there was no negative judgment. The participants assessed the e-learning courses as good $(69 \%)$ or neutral (31\%). As we can see the numbers given amount to $100 \%$, which means that none of the participants chose the "I don't know, we have not conducted such research" option. It means that, as a matter of fact, the above mentioned factor, that is the verification of the training's effects, is fully realized in the companies. A similar opinion, that is, no negative assessment, was presented by the training companies. Using the 1 to 5 scale of assessment, it turned out that the elearning most frequently got a decent three plus. No company "failed" the e-learning, while the fives appeared in the survey. Analyzing Figure 13, it can be said that it is a technology which is well assessed and it holds promise for the future. 


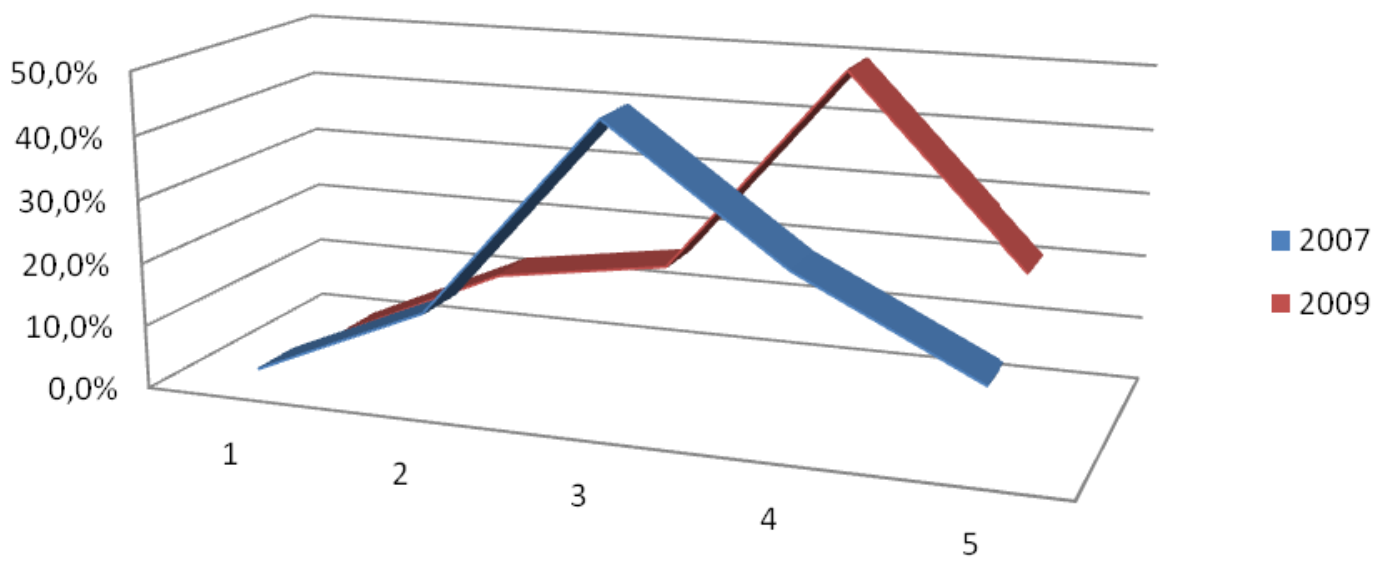

Figure 13. How the clients assess the e-learning trainings (in scale of 1 to 5)

(Source: own work based on the conducted research)

\section{Conclusion}

The analysis of two noticeable tendencies was conducted in the article, one of which concerns the necessity of adopting the policy aiming at building and developing the intellectual capital in the companies. The second, however, is a necessity of "cost cutting" in the operational activity. These are the requirements that the companies will have to face sooner or later. Resignation from one of the options can turn out to be unprofitable in the long run, therefore, the management is forced to create a strategy of compromise. We mean such compromise that enables savings which, at the same time, are not set aside at the expense of employees' development. We recommend a compromise strategy - the e-learning technology. This article presents the justification of this recommendation. It is believed that it is this teaching strategy that can turn out not only to be the most convenient and effective, but also economical. However implementing e-learning is indeed connected with high initial costs, the costs of e-learning and traditional training level off in a relatively short period of time. The introduction of e-learning as a method of training employees, analyzed in a long period of time, becomes a much more cost effective investment than the training methods used in a traditional way.

As the presented research and analysis of the literature showed, the opinion on the e-learning trainings varies, but in most cases it is positive. In the future we are planning to conduct surveys about the training's influence on professional development of those participants who successfully finished the training. We are especially interested in the training's impact on the career path of the employee. The organizations are aware of the fact that it is a technology that can dominate the training market in the future. The comparison of training methods conducted with the use of elearning methods and the ones that use traditional methods is difficult since the assessment research, especially as the traditional training, is not always carried out. The research on e-learning training conducted by the authors of the article usually finishes with an assessment questionnaire. As a result of an analysis of those questionnaires it can be explicitly stated that these training styles are seen and evaluated by both the companies and the participants as good. Also, the relation between the preparation of the participants of the training to the use of the e-learning platform and their assessment of the training is noticeable. In the case of people who have a good factual preparation to use the computers and the e-learning platform, the assessment is high, and, 
what is also connected, the assessment of the usefulness of such trainings is also high. The satisfaction of the participant is taken as measurement of the trainings' usefulness. We assume that the participant of the training will be able to determine best to what extent the training helped them in their career and if it influenced positively the development of the intangible assets of the company.

\section{References}

Argyris, C. (1999). On organizational learning (2nd ed.). Oxford: Blackwell Publishing.

Arvidsson, S. (2003). Demand and supply of information intangibles: The case of knowledge-intense companies. PhD Dissertation, Department of Business Administration, Finance, Lund University.

Bukowitz, W., \& Williams, R. (2001). Knowledge management fieldbook. Business Digest, February.

Choo, A., Lindermann, K., \& Schroeder, R. (2007). Method and psychological effects on learning behaviors and knowledge creation. Management Science, 53(March), 437-450.

Cohen, E. B., \& Nycz, M. (2006) Learning objects and e-learning: An informing science perspective. Interdisciplinary Journal of Knowledge and Learning Objects, 2, 23-34. Retrieved from http://ijklo.org/Volume2/v2p023-034Cohen32.pdf

Di Tommaso, M., Paci, D., \& Schweitzer S. (2002). The geography of intangibles. Paper prepared for the $3^{\text {rd }}$ PRISM Forum - Copenhagen, September $19^{\text {th }}-20^{\text {th }} 2002$

Edvinsson, L., \& Malone, M. (2001). Kapitat intelektualny [Intellectual capital]. Warszawa: PWN.

Fong, M. W. L., \& Sims, R. (2010). e-WIL in student education. Interdisciplinary Journal of E-Learning and Learning Objects, 6, 45-60. Retrieved from http://www.ijello.org/Volume6/IJELLOv6p045060Fong685.pdf

Garvin, D. A. (2006). Budowanie organizacji uczącej się [Building the learning organization]. Harvard Business Review. Zarzadzanie wiedza, Gliwice: Helion.

Hershhovitz, A., \& Nachmias ,R. (2009). Learning about online learning processes and students' motivation through web usage mining. Interdisciplinary Journal of E-Learning and Learning Objects, 5, 197214. Retrieved from http://www.ijello.org/Volume5/IJELLOv5p197-214Hershkovitz670.pdf

Huber, G. P. (1991). Organizational learning: The contribution process and the literatures [Special Issue: Organizational Learning: Papers in Honor of James G. March]. Organizational Science, 2(1), 88-115.

Hunter, L. (2002). Intellectual capital: Accumulation and appropriation. Melbourne Institute Working Paper No. 22/02, November 2002.

Jaspahara, A. (2006). Zarzadzanie wiedza. Zintegrowane podejście [Knowledge management: An integrated approach]. Warszawa: PWE.

Kisielnicki, J. (2005). Szkoła zarządzania informacją i wiedzą jako nowy kierunek rozwoju nauk organizacji i zarządzania [Knowledge management as a new trend in management science]. Problemy Zarzadzania No. 1.

Kisielnicki, J. (2008). MIS. Systemy informatyczne zarządzania. [Management information system]. Warszawa: Placet.

Koohang, A., Riley, L., Smith, T. J., \& Schreurs, J. (2009). E-learning and constructivism: From theory to application. Interdisciplinary Journal of E-Learning and Learning Objects, 5, 91-109. Retrieved from http://www.ijello.org/Volume5/IJELLOv5p091-109Koohang655.pdf

Lambe, P. (2007). Organising knowledge: Taxonomies, knowledge and organisational effectiveness. Oxford: Chandos Publishing.

Lee, C. C., \& Yang, J. (2000). Knowledge value chain. Journal Management of Development, 21(4), 783794. Retrieved from http://www.emeraldinsight.com/10.1108/02621710010378228 
Levitt, B., \& March, J. (1988). Organizational learning. Annual Reviews 1988, 319-340. Retrieved from http://www.education.umd.edu/EDPA/courses/EDPL74406/5.1.06\%20Levitt\%20and\%20March\%20Organizational\%20Learning1988.pdf.

Miller, P. (2007). Teoria stada [Theory of the herd]. National Geographic Polska No 8.

Nam, C. S., \& Smith-Jackson, T. L. (2007). Web-based learning environment: A theory based design process for development and evaluation. Journal of Information Technology Education, 6, 23-43. Retrieved from http://www.jite.org/documents/Vol6/JITEv6p023-043Nam145.pdf

Perechuda, K. (Ed.) (2005). Zarzadzanie wiedza w przedsiębiorstwie [Knowlegde management in organization]. Warszawa: PWN.

Probst, G., Raub, S., \& Romhardt, K. (2002). Zarzadzanie wiedza w organizacji [Managing knowledge: Building blocks for success]. Kraków: Oficyna Ekonomiczna.

Sela, E., \& Sivan, Y. Y. (2009). Enterprise e-learning success factors: An analysis of practitioners' perspective (with a downturn addendum). Journal of Information Technology Education, 5, 335-343. Retrieved from http://www.ijello.org/Volume5/IJELLOv5p335-343Sela674.pdf

Senge, P. M. (2006). Piata dyscyplina [The fifth discipline: The art \& practice of the learning organization]. Kraków: Oficyna Ekonomiczna Oddział PWP.

Shamir-Inbal, T., Dayan, J., \& Kali, Y. (2009). Assimilation online technologies into school culture. Journal of Information Technology Education, 5, 307-334. Retrieved from http://www.ijello.org/Volume5/IJELLOv5p307-334Samir-Inbal675.pdf

Smith, P. (1998). Systemic knowledge management: Managing organizational assets for competitive advantage. Journal of Systemic Knowledge Management, April.

Sobolewska, O. (2006). E-learning w szkoleniu kadr - raport z badań. Zarządzanie zasobami ludzkimi, 3-4 (48-49) 100-108.

Stankiewicz, M. J. (2006). Zarzadzanie wiedza, jako kluczowy czynnik międzynarodowej konkurencyjności przedsiębiorstwa [Knowledge management as a mail factor of company's international competition]. Toruń: Dom Organizatora.

Stata, R. (1989). Organizational learning - The key to management information. Sloan Management Review. Retrieved from http://www.google.com/books?hl=pl\&lr=\&id=vnyFFWL0loEC\&oi=fnd\&pg=PA31\&dq=stata + organiz ational+learning\&ots $=$ afYAKKp8hr\&sig=cI9Jg5vjGt5efymXn$\mathrm{WkdH} 3 \mathrm{MnnM} \# \mathrm{v}=$ onepage \& $\mathrm{q}=$ stata $\% 20$ organizational\%20learning $\& \mathrm{f}=$ false

Sveiby, K. E. (1997). The new organizational wealth: Managing \& measuring knowledge-based assets. San Francisco: Berrett-Koehler Publishers.

Sveiby, K. E. (2001). Intellectual capital and knowledge management. Retrieved from http://www.sveiby.com/

Sveiby, K. E. (2005). Dziesięć sposobów oddziaływania wiedzy na tworzenie wartości [Ten ways the knowledge affects on the value creation]. E-mentor, 2(9).

Tate, M., \& Hoshe, D. (2009). A model for the effective management of re-usable learning objects [RLOs]. Interdisciplinary Journal of E-Learning and Learning Objects, 5, 51-72. Retrieved from http://www.ijello.org/Volume5/IJELLOv5p051-072Tate412.pdf.

Vademecum Teleinformatyka (2004). Komunikacja mobilna, bezpieczeństwo, technologie i protokoły sieciowe. III tom [Mobile Communications, security, technologies and network protocols. Vol. III]. Warszawa: IDG. 


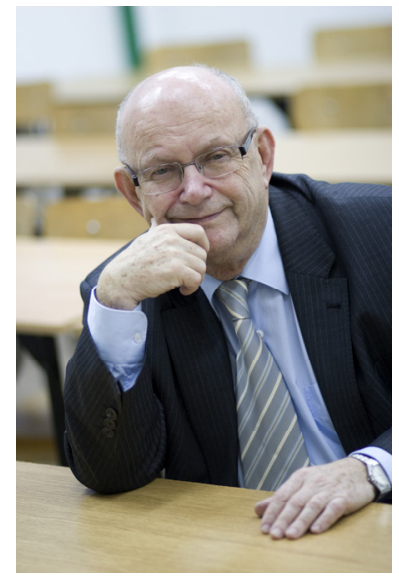

\section{Biography}

Jerzy Kisielnicki received a Ph.D. at the Warsaw School of Economics (S.G.P.i.S.) in 1969, and received a doctorate in 1969, and received a doctorate of Habilation in 1976 at the Warsaw University, Poland. He became a professor of economics in 1986, and he has been a full professor since 1992. Dr. Kisielnicki has been the head of the Department of Information Systems in Management and Faculty of Management at Warsaw University since 1972, and has been the head of the Department of Management at Marketing at the School of Economics (WSHiP) since 1995.

His interests are organization and management, systems analysis, management information systems, e-learning, process innovation (reengineering), strategic management, and transition systems organisation and management in market economy. He is a member Institute for Operations Research and the Management Science TIMS-ORSA. Dr. Kisielnicki is a member of the Board of Organization and Management in Polish Academy of Science and is the head of the Scientific Council of Polish Society of Systems Information. He has had about 220 publications.

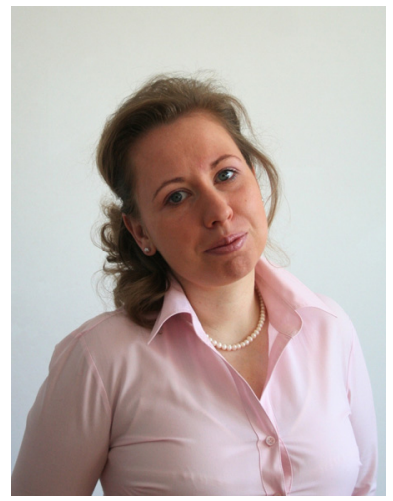

Olga Sobolewska is a postgraduate at Warsaw University Faculty of Management. She received the master degree in economics in 2004 from the Warsaw University and the engineer degree in information technologies in 2005.

She is currently working towards a professional doctorate. Her research interest includes information technology, knowledge management, ebusiness and online education. Her main area of expertise is ICT supported learning. 